IRSH 52 (2007), pp. 353-36I DOI: I0.1017/S0020859007002982

(C) 2007 Internationaal Instituut voor Sociale Geschiedenis

\title{
GUIDE TO THE INTERNATIONAL ARCHIVES AND COLLECTIONS AT THE IISH: SUPPLEMENT OVER 2006*
}

In 2000 a new edition of the 'Guide to the International Archives and Collections at the IISH, Amsterdam' (henceforth cited as GIA) was published. A description of recently acquired archives and collections as well as major accruals to archives received by the IISH will be published annually to keep this survey up to date. Like the GIA this supplement is subdivided into the categories 'persons', 'organizations' and 'subjects', arranged alphabetically.

As to the summaries the following components can be discerned:

I. Access: As a rule consultation is not restricted; any restrictions are indicated by *.

2. Name: Names of persons include dates of birth and death when known. In the case of international organizations with names in more than one language, the name chosen corresponds to the language in which most of the documents were written. Among organizations that have changed their names, the one used most recently was selected. Previous names of organizations are mentioned in the condensed biography or history. The names of subject collections are mostly in English.

3. Period: First and last date of the documents present. Where only a few documents are from a certain year or period, they are listed between parentheses.

4. Size: In linear metres.

5. Finding aid: Available inventories (published and unpublished), lists and indexes.

6. Biography/history: A condensed biography or history of the persons or organizations concerned.

7. Summary of the contents: A summary of the contents of the archives, papers or collection concerned.

Reference is given to the pages of the GIA holding the initial description where summaries of an accrual are concerned.

The summaries of this supplement will also be added to the survey of archival collections on the Internet website of the IISH (http://www.iisg.nl). Summaries of the Dutch collections of the IISH can be found in the survey on the Internet website too.

The archives may be consulted in the reading room of the IISH. Requests for documents should include their inventory or list numbers. For further information about the rules for access and consultation (including rules on procedures for handling the material and making photocopies) users should contact the information service of the IISH (e-mail: vid@iisg.nl).

\footnotetext{
* Edited by Bouwe Hijma
} 


\title{
I. Persons
}

\section{Berruezo Silvente, José (I895-1990) \\ Period: $1944-1984$}

\section{Size: $1.5 \mathrm{~m}$.}

Born in Mazarrón, Spain I895, died Aix-en-Provence, France 1990; as a disciple of Raja and Martínez Izquierdo at the age of fourteen he distributed leaflets to the miners in his native village; two years later he was detained for having realized anarchist graffiti and imprisoned in Totana; moved to Barcelona I919, working in the construction of the barrage of Camarasa; settled in Santa Coloma de Gramanet 1920, which from then would be his centre of activities; participated in the foundation of the Ateneo and the CNT of Santa Coloma, of which he was elected secretary I922; during the dictatorship of Primo de Rivera, 1920-1930, collaborated in reorganizing the CNT and forming a prisoners' solidarity group; after the proclamation of the Second Spanish Republic I93 I he was, together with Gregorio Jover, in charge of the rationalistic school of Santa Coloma; participated in the Second Congress of the CNT in Badalona; imprisoned several times between 1932 and 1935; teacher at the school of the Ateneo of San Adrián 1936; during the Civil War in charge of public health in the Revolutionary Antifascist Committee of Santa Coloma, and deputy in the municipal council from October 1936 until the end of the war; in May 1937 and in 1938 I 939 also mayor of Santa Coloma; went in exile in January 1939, and in France cooperated actively in reorganizing the CNT as a delegate from the regional section of Aynes-Cantal, of which he had been elected secretary; participated in the plenary meeting in Toulouse in 1945 that dealt with the decision of the clandestine CNT in Spain to take part in the republican government in exile; after that his activities diminished awaiting, like so many others, the fall of Franco; after the death of Franco in 1975 he visited Spain again, but did not return; his articles were published in Asturias, Aurora Libre, El Diluvio (1930-1931), Sindicalismo of Madrid (1977) and Solidaridad Obrera (using the pseudonym Clarín); he wrote Contribución a la historia de la CNT de España en el exilio (Mexico, 1967), and Por el sendero de mis recuerdos (Santa Coloma, 1987).

Extensive correspondence with many anarcho-syndicalists in France and abroad, from I 944 until I984, including a.o. Ginés Alonso, Ramón Álvarez, José Berruezo Romera, Jacinto Borrás, Juan Ferrer, Lola Iturbe, Ramón Liarte, Bernardo Merino, Juan Manuel Molina, Helenio Molina, Manuel Rico, and Pastor Sevilla; correspondence with the local federation of Marseilles I960-1965 and with the confederal organizations in Mexico, Venezuela, and Sweden (SAC) I952-I972; a file on Manuel Morey Blanch; minutes, circulars and other documents concerning the regional section Aynes-Cantal I944-I948; the local federation of Bort-les-Orgues (Corrèze) 1947-1954; the local federation of Gap (Hautes Alpes) 1954-1959; and the local federation of Marseilles I960-1968; minutes of the plenary meetings of the National Committee in France 1944-1945; and of the National Sub-Committee 1945-1947; various circulars and reports 1945-1960; documents concerning the 'Grupos de Presencia Confederal' i966-1977; and concerning the 'Cinco Puntos' (the so-called 'gestiones de Madrid') I965-i968; typescripts of his book Contribución a la historia de la CNT de España en el exilio 1967, 1975, including a file of letters and other documents on the subject I943-I975 and n.d.

\author{
Bouvard, Marguerite Guzmán (born 1937) \\ Period: 1977-1996 \\ Size: $0.25 \mathrm{~m}$. \\ Finding aid: list (non-digital)
}


Born in Trieste, Italy 1937; studied at Harvard University and Boston University in the United States; for many years Professor of Political Science and Creative Writing at Regis College, Weston, MA and director of poetry workshops; since 1991 Resident Scholar with the Women's Studies Research Center at Brandeis University, Waltham, MA; founding editor of the All Sides of Ourselves publication series; studied and worked together with the 'Madres de Plaza de Mayo', the mothers of the disappeared children of Argentina.

Documents on the foundation of the Madres de Plaza de Mayo, their actions and those of Amnesty International, resolutions of the European Parliament, the positions of the Madres on exhumations and economic reparation, testimonies of the Madres on the camps and the practice of secret detention, and transcripts of interviews with a lot of them 1977-1996.

\section{*Creagh, Ronald (born 1929) \\ Period: $1950-1990$ \\ Size: $3.5 \mathrm{~m}$.}

Born in Alexandria, Egypt 1929; Professor of American Civilization at the University of Montpellier, France.

Correspondence, manuscripts, documentation, and other documents concerning atheism, laicization, religion and youth, anarchism, free-thinkers I950-I990.

\section{*Dikerdem, Mahmut Şerafettin (I916-1993)}

Period: 1946-1993 (-2006)

\section{Size: $0.5 \mathrm{~m}$.}

Born 1916, died Istanbul 1993; Turkish diplomat and peace activist; graduated in law from Istanbul University 1938; joined the Foreign Ministry 1939; ambassador in Jordan, Iran, Ghana, and India 1957-1972; became the founding president of the Turkish Peace Association (Barış Derneği) 1977; arrested in 1982 after the 1980 military coup and charged with making propaganda for communism; nominated for the Nobel Peace Prize 1985; released the same year from prison.

Correspondence mainly with his son Mehmet Ali Dikerdem including letters sent from prison 1969-I992; typescripts, clippings, and copies of articles, interviews, and speeches I946-I992; documents concerning his death, the Turkish peace movement, foreign policy, and the trial against the Turkish Peace Association 1970-1993 $(-2006)$.

Gaillard, André C.J. (1909-2000)

Period: 1909-1997

Size: $0.25 \mathrm{~m}$.

Born in Paris 1909, died in Paris 2000; lifelong active Esperantist and vegetarian.

Correspondence including documents on naturist-Esperantist groups in France I929-I932, I947, I949; collection of examples of small Esperantist periodicals and pamphlets from a large range of countries (Austria, Belgium, Brazil, Bulgaria, 
Czechoslovakia, Estonia, France, Germany, Great Britain, Hungary, Italy, Lithuania, Poland, Romania, Sweden, Switzerland, United States) I909-I997.

\section{Htein Lin (born I966) \\ Period: $1988-2006$ \\ Size: $0.25 \mathrm{~m}$.}

Born Ingapu, Irrawaddy Division, Burma 1966; studied at Rangoon University; took part in political protests 1988; spent four years in exile on the Indian border; worked as an artist and comic actor and pioneered performance art in Burma with 'The little worm in the ear' and 'Guitarist', street performances in downtown Yangon 1996; solo exhibitions in Yangon 1996I997; arrested on fabricated political charges in 1998 but in jail was able to paint and to perform; since his release in the autumn of 2004 has had three solo shows in Yangon, '00235' which shows his prison paintings; 'Recycled', an exhibition accompanied by 'Standstill', a daily performance comprising four hours of standing meditation; and 'Come Rain or Shine', an exhibition of recent works; in May 2005 Htein Lin and colleagues were detained briefly following their street performance entitled 'Mobile Art Gallery and Mobile Market'.

Documents on the National League for Democracy (NLD) and ethnic parties 20032006; documents on the National Convention I996-2006; various documents from I 988 on.

\section{Marin, Eugène Gaspard (1883-1969) \\ Period: $1905-1964$}

Size: $0.12 \mathrm{~m}$.

Born Boitsfort, Belgium I 883, died I969; born into a well-to-do Walloon Belgian family; in I 905 became acquainted with the anarchist commune of Emile Chapelier, located in Stockel-Bois from 3 April of that same year and later transferred to Boitsfort, both near Brussels; the commune, named 'L'Expérience' (The Experiment) and with the parole 'Nous n'avons ni dieu ni maître' (We have neither God nor master), was dedicated to the principles of common property, free love, vegetarianism, anti-militarism, and anti-colonialism; those who joined later included Dutch deserters; in February 1908 the colony fell apart as a result of internal tensions and external opposition; Marin fled to England and joined the anarchist-Tolstoyan Whiteway Colony near Gloucestershire, where he lived until his death.

Photocopies of a handwritten diary including a report by Emile Chapelier and Gassy Marin on the communist-libertarian colony near Brussels I905-1908; proposal for experimental cooperative communities in Mexico I923; food distribution ration books I939-I954; some documentation I9II-I964.

\section{${ }^{*}$ Myo Win (born 1965) \\ Period: 1994-2002 \\ Size: $1.5 \mathrm{~m}$.}

Born Tavoy, Burma 1965; studied at the Rangoon Institute of Technology until the uprising of 1988; joined the All-Burma Students' Democratic Front (ABSDF) and eventually became its General Secretary; also board member of the National Council of the Union of Burma (NCUB), the Democratic Alliance of Burma (DAB), and the Forum for Democracy in Burma (FDB). 
Minutes of meetings, correspondence, diaries, files on internal policy debates 19942002.

\author{
Pechmann, Erich (1900-1978) \\ Period: $1914-1958$ \\ Size: $0.12 \mathrm{~m}$. \\ Finding aid: list
}

Born Berlin 1900, died Amsterdam (?) 1978; photographer in Kassel, also plaster modeller; in prison because of his candidature for the city council of Kassel on the KPD list 1933; discharged I934 but in spite of this in concentration camp Breitenau 1934; emigrated to the Netherlands I936; stayed there illegally and participated under the pseudonyms K. Wagner and Klaas 3373 in committees supporting the communist radio station ' 29,8 '; during the German occupation of the Netherlands active in the resistance; participated after the liberation in the Vereinigung Deutscher und Staatenloser Antifaschisten in den Niederlanden (VDSA); expelled from the Netherlands 1954, but returned after his marriage with Catharina Sara Noach 1954-1956.

Personal documents 1914-1958; correspondence 1946-1948; file on his support of the communist radio station ' 29,8 ' 1937-1940; file on the Dutch aliens policy and the expulsion of German anti-fascists from the Netherlands 1937-1938; file on the expulsion of Pechmann from the Netherlands and his return after marriage 19541956.

\title{
Polster, Johannes (1893-1979) \\ Period: 1974 (1990) \\ Size: $0.0 \mathrm{I} \mathrm{m}$.
}

Born I893, died 1979; teacher at a technical school in Döbeln, Saxony, Germany; arrested by East German police in 1945 and imprisoned by the Soviet occupation forces in the NKVD camp Mühlberg until 1947 .

Copy of a typescript on his stay in NKVD camp ('Speziallager') Mühlberg I974. NB. This 1974 version of the text of Johannes Polster was typed, edited, and enlarged with an epilogue by his son Theodor Polster in 1990.

\section{Rappoport, Charles (1865-I94I) \\ Period: 1915-194I (-1994) \\ Size: $0.25 \mathrm{~m}$.}

Accrual: for initial description see GIA, p. I80.

Correspondence with Gaston Bergery 1939, Jean Marestan 1936, Pierre Morhange I929-1930, Romain Rolland I9I5, Georges Sadoul 1936, Maurice Thorez I937, Henry Torrès 1928, and others I915-1941; file on Jean Jaurès n.d.; file on his contributions to the Izvestija 1930-1934; typescripts 'Élaboration de la conception Marxiste' I919, 'La première révolution sociale victorieuse' n.d., 'Mon séjour en URSS'/'Mon voyage en Russie' 1927-1928, 'Calendrier philosophique' [1936], 'M. Staline est-il le diable de "Faust"' [1939] and other; original typescript, with notes, of and correspondence on the memoirs of Rappoport, annotated by Harvey Goldberg 
and Georges Haupt, edited by Marc Lagana and published as Une vie révolutionnaire I883-1940. Les mémoires de Charles Rappoport in I991, I990-I994.

\title{
*Samary, Catherine \\ Period: 1949-1989 \\ Size: $0.25 \mathrm{~m}$.
}

Born Cannes, France; in her youth active in the Parti Communiste Français; at the age of eighteen member of the French section of the Fourth International; member of the Union Nationale des Étudiants de France; studied economics in Paris; university teacher of economics at the University of Paris-Dauphine; researcher at IRISES ('Institut de recherche interdisciplinaire en sociologie, économie, science politique'), University of Paris-Dauphine, on the European construction and the systematic transitions on the Balkans (in particular the earlier Yugoslavia) and in eastern Europe.

Documents regarding discussions within the Fourth International on the developments within Yugoslavia 1949-1951; China 1952-1955; documents on the Fourth and the Fifth World Congress of the Fourth International 1953-1954, 1957; documents on the 9th World Trade Union Congress, organized by the World Federation of Trade Unions, in Prague in April 1978 and the role of Charta 77 in Czechoslovakia and Solidarnosc in Poland 1977-1981; documents on the developments within the Soviet Union 1981-1989.

\section{Zahlbaum, Willi (1914-2002) \\ Period: c. 1992}

Size: $0.02 \mathrm{~m}$.

Born Berlin 1914, died Berlin 2002; with social democratic parents, Zahlbaum was as a child member of the Rote Falken; joined the socialist Sozialistischer Jugendverband 1932 and the Sozialistische Arbeiterpartei 1933; did illegal work after the Nazi seizure of power; arrested in early 1935 and imprisoned for eighteen months; forced to serve in 'Strafdivision 999' 1942; taken prisoner 1943; stayed in French prisoner of war camp Bizerte in Tunisia 1943-1947; returned to Berlin 1947; worked as a radio and television journalist; resigned as head of the DEFA-Studio für Wochenschau und Dokumentarfilme 1962; secretary of the Vietnam solidarity committee of the GDR I965-I975; left the SED in early November I989 and became an SPD member in his later years.

Copy of his typescript 'Zwei Sommer im Preußischen Strafgefängnis Berlin-Tegel' (Two summers in Prussian prison Berlin-Tegel) c. 1992.

NB. A revised version of this typescript is published in his memories Aufrecht gehen (200I).

\section{Organizations}

\author{
Autonomie. Materialien gegen die Fabrikgesellschaft \\ Period: $1975-1982$ \\ Size: $2.75 \mathrm{~m}$.
}

Autonomie. Materialien gegen die Fabrikgesellschaft was between 1975 and 1985 an irregularly issued, self-styled left-radical, periodical of the German autonomous scene; former members of 
the Frankfurt Group 'Revolutionärer Kampf' took part in the Hamburg-based editorial committee of this periodical published by Trikont-Verlag in Munich.

Correspondence, typescripts, and documentation related to the compiling of the various numbers of this periodical with such themes as state power, the arms race, the labour market, housing policy, town planning, and criminality, attitudes against foreigners, the Islamic Revolution in Iran and the war between Iran and Iraq 19751982.

\section{CNT en el exilio}

Period: $1963-1966$

Size: $0.04 \mathrm{~m}$.

The Confederación Nacional del Trabajo (CNT) in exile organized its meetings in the 1960s in France and sometimes illegally across the border in Spain.

Bulletins and circulars, collected by Antonio Roda Vallés (died at the age of fiftyeight in Val de Marne, France 1966), containing the records of the meetings of the various boards within the Confederación Nacional de Trabajo in exile, held in France and in Spain 1963-1966.

\section{*International League of Religious Socialists (ILRS) \\ Period: 1979-2003 \\ Size: $\mathrm{I}$ m.}

The International League of Religious Socialists was founded in the I920s; in the beginning it was more or less a German-speaking body with its base in northern Europe; the Christian Socialist movement in Great Britain joined later; the ILRS has most of its member organizations in Europe but expanded also throughout the world; the ILRS is an associate organization of the Socialist International; Evert Svensson (born in Bergum, Älvsborg, Sweden 1925), also for a long time member of the Swedish Parliament for the Swedish Social Democratic Party (I957-1991), was President of the League 1983-2003.

Minutes of the meetings of the executive committee of the ILRS and correspondence 1979-2003; documents on the ILRS-congresses in Managua, Nicaragua I986, Helsingfors, Finland 1997, Budapest 2000, and Lucerne 2003; documents on the peace process, human rights, and various development projects in Nicaragua I984I988.

\section{South Africa Economic Research and Training Project (SAERT) Period: (1983-) 1985-1992 (-1995) \\ Size: $0.37 \mathrm{~m}$.}

The South Africa Economic Research and Training Project (SAERT) was founded in Amsterdam 1985; the general objective of the project was to establish a research centre in one of the independent African states; the envisaged centre was intended to provide a focus for research work into the development of post-apartheid South Africa; aims were oriented at training personnel as well as documentation of all available material on subjects and areas that are relevant for the study of the South African economy; in 1992 SAERT director Selebano 
Matlhape was allowed to transfer SAERT to South Africa and to incorporate the SAERT project into the local structures; he was authorized to hand over the administration and SAERT operations to the Mangaung Education and Development Trust (MEDET) and to continue SAERT's activities from within South Africa.

Correspondence 1985-1994; file on the foundation of SAERT I 985 ; file on the Board of Trustees 1985-1986; file on the workshop, organized by SAERT, on 'Research Priorities for Socio-Economic Planning in Post-Apartheid South Africa' in Amsterdam December 1986, I986-1987; file on the cooperation with the African National Congress I983-I99I; minutes of the meetings of the board of the Mangaung Education and Development Trust (MEDET) I99I-I992; file on the transfer to South Africa I991-i995.

\section{Subjects}

\section{Events in Burma around $1988-1989$}

\section{Period: $1988-1989$}

Size: $0.12 \mathrm{~m}$.

Finding aid: list (non-digital)

In 1988 there was a nationwide pro-democracy uprising in Burma; the military government suppressed the protests of students and others; as a result of the movement of 1988 the National League for Democracy, led by Daw Aung San Suu Kyi, won the elections of May r 990 but the military government refused to transfer power; the Burmese opposition in exile is still fighting the government.

Letters, opinions, pamphlets, press releases, statements and other documents on the army, ethnic groups, human rights, the student and youth movement, the All-Burma Federation of Students' Unions, the Democratic Party for a New Society, the National League for Democracy, Daw Aung San Suu Kyi and other persons and organizations, all in relation to the events in Burma around I988 and I989 I988-1989.

\section{Reproductions}

\section{Fuerzas Armadas Peronistas}

\section{Period: I968-I991}

Size: $0.03 \mathrm{~m}$.

The Fuerzas Armadas Peronistas (Peronist Armed Forces) were founded as a movement in 1967; the Marxist militant group 'Vasco' Bengochea was dominating the organization; the FAP refused to integrate in the official structures of Peronism; a section of the FAP, led by Carlos Caride and Envar 'Cacho' El Kadri (194I-1998), separated in I 973 and formed the 'FAP I7 de Octubre'; under the Argentine military dictatorship between 1976 and 1983 the members of the FAP were heavily persecuted.

Photocopies of documents from the FAP itself, photocopies of 'confidential' and 'secret' government documents on the detention of and processes against the members of the FAP during the military dictatorship in Argentina and photocopies of documents on the history of the FAP i968-i99i. 


\section{Kurzweil, Bruno (1891-1942)}

Period: 1909-1942 (-I993)

\section{Size: 0.1 I m.}

Born in Josefstadt, Bohemia, Austria I891, died in Auschwitz 1942; studied law; lawyer in Graz; member of the Social Democratic Party in Austria in the I930s; fled with wife and daughter to France I938, where they lived separately while their daughter Adèle lived in a children's home in Montmorency; eventually Kurzweil and his wife Gisela and their daughter were handed over by the Vichy government to the German authorities, deported to and murdered in Auschwitz 1942; the original documents were found in a box hidden behind the ceiling of a police station in a village near Montauban, France 1990.

Photocopies of correspondence, identity papers, travel and other documents concerning the family Kurzweil, their flight from Austria and their stay in France I909-I942 (-I993). 